\title{
CHEMICAL FRACTIONATION OF BRINE IN THE MCMURDO ICE SHELF, ANTARCTICA
}

\author{
By James H. Cragin, Anthony J. Gow, and Austin Kovacs
}

(U.S. Army Cold Regions Research and Engineering Laboratory, Hanover, New Hampshire 03755, U.S.A.)

ABSTRACT. During the austral summers of 1976-77 and 1978-79, several ice cores were taken from the McMurdo Ice Shelf brine zone to investigate its thermal, physical, and chemical properties. This brine zone consists of a series of superimposed brine layers (waves) that originate at the seaward edge of the ice shelf and migrate at various rates, depending on their age and position in the ice shelf. The brine in these layers becomes increasingly concentrated as the waves migrate inland through the permeable ice-shelf firn. Chemical analyses of brine samples from the youngest (uppermost) brine wave show that, except for the advancing front, it contains sea salts in normal sea-water proportions. Further inland, deeper and older brine layers, though highly saline $\left(S>200^{\circ} / 00\right)$, are severely depleted in $\mathrm{SO}_{4}^{2-}$, with the $\mathrm{SO}_{4}{ }^{2-} / \mathrm{Na}^{+}$ratio being an order of magnitude less than that of normal sea-water. Consideration of the solubility of alternative salts, together with analyses of $\mathrm{Na}^{+}, \mathrm{K}^{+}, \mathrm{Ca}^{2+}$, $\mathrm{Mg}^{2+}, \mathrm{SO}_{4}{ }^{2-}$, and $\mathrm{Cl}^{-}$concentrations, shows that the sulfate depletion is probably due to selective precipitation of mirabilite, $\mathrm{Na}_{2} \mathrm{SO}_{4} \cdot 10 \mathrm{H}_{2} \mathrm{O}$. The location of the inland boundary of brine penetration is closely related to the depth at which the brine encounters the firn/ice transition. However, a small but measureable migration of brine is still occurring in otherwise impermeable ice; this is attributed to eutectic dissolution of the ice by concentrated brine as it moves into deeper and warmer parts of the McMurdo Ice Shelf.

RÉsumÉ. Fractionnement chimique de la saumure sur le McMurdo Ice Shelf, Antarctique. Au cours des étés austraux 1976-77 et 1978-79 plusieurs carottes ont été extraites de la zone de saumure du McMurdo Ice Shelf pour la détermination de ses propriétés thermiques, physiques et chimiques. Cette zone de saumure est constituée de séries de couches superposées de saumure (vagues) qui prennent naissance à la frontière marine du Shelf et migrent à des vitesses différentes, suivant leur áge et leur position sur le shelf. La saumure dans ces couches augmente en concentration à mesure que les vagues progressent vers l'intérieur à travers le névé perméable du Shelf. Des analyses chimiques d'échantillons de saumure pris dans les vagues les plus récentes (partie supérieure) montrent que, à l'exception du front de progression, elle contient des sels marins dans les proportions normales de l'eau de mer. Plus loin à l'intérieur, dans des couches de saumure plus profondes et plus anciennes, malgré leur forte salinité $\left(S>200^{\circ} / 00\right)$ elles sont fortement appauvries en $\mathrm{SO}_{4}{ }^{2-}$, avec

\section{INTRODUCTION}

Sea-water infiltration into porous ice shelves has been observed at a number of Antarctic locations (Dubrovin, 1962; Yevteyev, 1962; Stuart and Bull, 1963; Heine, 1968; Thomas, 1975; Kovacs and Gow, 1975, 1977; Kovacs and others, 1982[a]). Much of the past work has focused on either determining the geographical extent of the brine penetration inland using radio echo-sounding techniques (Clough, 1973; Kovacs and Gow, 1975) or on studying iceshelf brine thermodynamics (Thomas, 1975). Initially, brine- une proportion $\mathrm{SO}_{4}{ }^{2-} / \mathrm{Na}^{+}$d'un ordre de grandeur inférieur à celui habituel dans l'eau de mer. En prenant en compte la solubilité d'autres sels, ainsi que l'analyse des concentrations de $\mathrm{Na}^{+}, \mathrm{K}^{+}, \mathrm{Ca}^{2+}, \mathrm{Mg}^{2+}, \mathrm{SO}_{4}{ }^{2-}$ et $\mathrm{Cl}^{-}$on montre que l'appauvrissement en sulfate et probablement da à une précipitation sélective de mirabilite, $\mathrm{Na}_{2} \mathrm{SO}_{4} \cdot 10 \mathrm{H}_{2} \mathrm{O}$. La frontière intérieure de pénétration de la saumure est en étroite relation avec la profondeur à laquelle la saumure rencontre la transition névé/glace. Cependant, une faible mais mesurable migration de saumure intervient encore même dans la glace imperméable; cela est attribué à la dissolution eutectique de la glace par la saumure concentrée à mesure qu'elle progresse dans les parties plus profondes et plus chaudes du McMurdo Ice Shelf.

Zusammenfassung. Chemische Fraktionierung von Salzsole im McMurdo Ice Shelf. Antarktika. Während der Südsommer 1976-77 und 1978-79 wurden einige Bohrkerne aus der Solezone des McMurdo Ice Shelf gezogen, um dessen thermische, physikalische und chemische Eigenschaften untersuchen zu können. Die Solezone besteht aus einer Serie von aufgelagerten Soleschichten (Wellen), die am seeseitigen Rand des Schelfeises ihren Ausgang nehmen und in Abhăngigkeit von ihrem Alter und von ihrer Lage im Schelfeis mit verschiedenen Geschwindigkeiten wandern. Die Solekonzentration in diesen Schichten nimmt bei der Wanderung der Wellen landeinwärts durch den durchlässigen Firn des Schelfeises zu. Chemische Analysen von Soleproben aus der jüngsten (obersten) Solewelle zeigen, dass sie, mit Ausnahme der vorrückenden Front, Meeressalz von normalen Meerwasserproportionen enthält. Weiter landein haben tiefere und åltere Soleschichten, obwohl sie hohen Salzgehalt $(S>200 \%$ aufweisen, einen stark verringerten $\mathrm{SO}_{4}^{2-}-$ Gehalt, wobei das $\mathrm{SO}_{4}^{2-}-\mathrm{Na}^{+}-$Verhăltnis eine Grőssenordnung kleiner als bei normalem Meerwasser ist. Die Betrachtung der Lőslichkeit von alternativen Salzen zeigt zusammen mit Analysen der $\mathrm{Na}^{+}-, \mathrm{K}^{+}, \mathrm{Ca}^{2+}-, \mathrm{Mg}^{2+}$, $\mathrm{SO}_{4}{ }^{2-}-$ und $\mathrm{Cl}^{-}-$Konzentration, dass die Sulfatabnahme vermutlich auf den selektiven Niederschalg von $\mathrm{Na}_{2} \mathrm{SO}_{4} \cdot 10 \mathrm{H}_{2} \mathrm{O}$ zurückzuführen ist. Die Lage der Grenze der Soledurchdringung landeinwărts hăngt eng mit der Tiefe zusammen, in der die Sole auf den Übergang von Firn in Eis trifft. Dort tritt eine geringe, aber messbare Wanderung von Sole auch im sonst undurchlässigen Eis auf; dies wird auf die eutektische Zerstörung des Eises durch konzentrierte Sole bei der Bewegung in tiefere und wärmere Teile des McMurdo Ice Shelf zurückgeführt.

layer formation was believed to be due to vertical infiltration of sea-water into porous firn (Stuart and Bull, 1963) but Risk and Hochstein (1967), and Kovacs and Gow (1975), have concluded from their observations on the McMurdo Ice Shelf that lateral infiltration of sea-water from the ice-shelf edge is the dominant mechanism of brine infiltration. More recent observations by Kovacs and others (1982[b]) show that lateral infiltration is itself dominated by wave-like intrusions of sea-water triggered by periodic break-out (calving) of the ice front in McMurdo Sound.

In order for brine to remain liquid at the temperature 
encountered in ice shelves, excess water must be eliminated by freezing within the pores of the permeable firn. Freezeconcentration could also lead to significant changes in brine chemistry. The only reported chemical measurements of the composition of the infiltrated brine are those of Wilson and Heine (1964) and Heine (1968), who observed a SO * depletion relative to $\mathrm{Cl}$ in the brine layer of the McMurdo Ice Shelf. They attributed this to preferential precipitation of mirabilite. Here we report results of more extensive chemical analyses of a series of ice cores taken from the top of the brine layer in the McMurdo Ice Shelf.

\section{EXPERIMENTAL PROCEDURES}

\section{Core drilling and sampling}

An electro-mechanical drill designed by Rand (1976) was used to obtain $10 \mathrm{~cm}$ diameter cores from the snow surface down to about $3 \mathrm{~m}$ into the brine layer. In this particular drill the electrical section leading to the motor was not designed to operate in liquids, so it was not possible to drill deeper than about $3 \mathrm{~m}$ into the brine layer. We obtained additional cores with a modified SIPRE coring auger. Cores were drilled at the locations shown in Figure 1. The cores labeled 77 High Step and 77 Low Step were drilled during January 1977; cores from locations A, B, C, D, and E were drilled during November 1978.

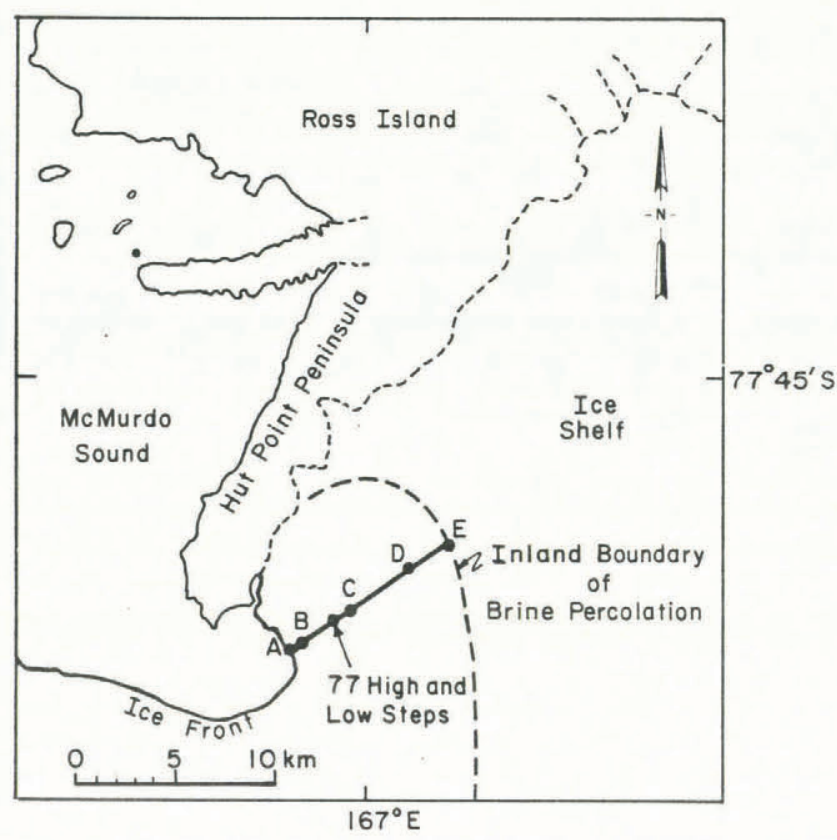

Fig. 1. Sketch map of the McMurdo Ice Shelf area showing the main profile line and core-drilling locations.

Sections of brine-soaked firn and ice were cut from cores at about $10 \mathrm{~cm}$ intervals, melted in polyethylene containers and transferred to glass vials for shipment to CRREL for chemical analysis.

\section{Cation analyses}

We performed cation analyses for $\mathrm{Na}, \mathrm{K}, \mathrm{Ca}$, and $\mathrm{Mg}$ on the melted samples, which had been diluted by factors of $10^{4}$ to $10^{6}$, depending upon the element and the sample salinity. Concentrations were determined on $20 \mu \mathrm{l}$ aliquots by graphite-furnace atomic absorption using a Perkin-Elmer Model 403 AA spectrophotometer in conjunction with a

*For brevity and ease of typesetting, ionic charges have been omitted from the elemental symbols. It should be noted, however, that measurements and ratios reported are those for the respective ions.
Model 2200 heated graphite atomizer. Deuterium background correction was unnecessary at the low concentrations $(\mu \mathrm{g} / \mathrm{l})$ of the diluted samples. Analysis for $\mathrm{Na}$, however, did require a maximum temperature (approximately $2700^{\circ} \mathrm{C}$ ) heating step after each atomization to remove residual salts and to prevent interference in the signal of subsequent aliquots. Standards, prepared fresh daily from Fisher $1000 \mathrm{mg} / 1$ stock solutions, and samples were analyzed in triplicate.

\section{Sulfate and chloride analyses} Sulfate concentrations

were

determined turbidimetrically using $\mathrm{BaCl}_{2}$ with a stablizing agent to form a $\mathrm{BaSO}_{4}$ suspension. Samples were diluted by factors of 2-100 to bring their $\mathrm{SO}_{4}$ concentrations into the analytical working range of $5-50 \mathrm{mg} / \mathrm{l}$. Absorbances were measured in $2.5 \mathrm{~cm}$ cells at $450 \mathrm{~nm}$ with a Hach DR/2 spectrometer.

As a check on the above turbidimetric method, we also analyzed selected samples for $\mathrm{SO}_{4}$ using the more involved barium chloranilate technique (Bertolacini and Barney, 1958; Shafer, 1967) modified as previously described (Cragin and others, 1975) without sample pre-concentration. A comparison (Table I) of results of these two methods shows excellent agreement.

TABLE I. COMPARISON OF SULFATE DETERMINED BY TURBIDIMETRIC (BARIUM SULFATE) AND COLORIMETRIC (BARIUM CHLORANILATE) TECHNIQUES SAMPLES ARE FROM THE 77 HIGH AND 77 LOW STEP CORES

\begin{tabular}{ccc} 
Sample & \multicolumn{2}{c}{$\begin{array}{c}\text { SO } \\
\text { 4 concentration } \\
\mathrm{g} / 1\end{array}$} \\
1A & Turbidimetric & Colorimetric \\
2 & $3.4 \pm 0.1^{*}$ & 3.8 \\
5A & $2.4 \pm 0.1$ & $2.5 \pm 0.1$ \\
5B & $2.2 \pm 0.1$ & $2.3 \pm 0.1$ \\
33C & $2.4 \pm 0.1$ & $2.5 \pm 0.1$ \\
34B & $0.55 \pm 0.03$ & $0.57 \pm 0.02$ \\
& $0.60 \pm 0.02$ & $0.60 \pm 0.01$
\end{tabular}

*Standard deviations shown are for triplicate analyses. For the colorimetric analysis of sample 1A, sufficient sample was available for only a single analysis.

Chloride concentrations were determined potentiometrically using an Orion solid-state $\mathrm{Cl}$ electrode and an Orion double-junction reference electrode with $1 \mathrm{M} \mathrm{KNO}_{3}$ filling solution in the outer chamber. Standards containing $5-50 \mathrm{mg} \mathrm{Cl} / 1$ were prepared from a $1000 \mathrm{mg} \mathrm{Cl} / 1$ stock solution of "Specpure" $\mathrm{NaCl}$ (Johnson, Mathey and Co., Ltd). Samples were diluted $10-1000$ times to bring their $\mathrm{Cl}$ concentrations into the working range of the standards.

Precision of all the above chemical analysis methods was $\pm 10 \%$ or better.

\section{Sea-water analysis}

As an additional verification of the accuracy of the analytical methods used, a sample of Copenhagen Standard Seawater (CSS) was diluted appropriately and analyzed along with the brine samples. Measured concentrations, included in Tables II and III, conform very closely to the expected values.

\section{RESULTS AND DISCUSSION}

\section{Core locations}

Figure 2 presents a cross-section of the McMurdo Ice Shelf in the area of interest. It shows the location of drill holes that penetrated brine, together with the brine layer and ice-shelf bottom as determined by drilling and radar profilometry (Kovacs and Gow, 1977; Kovacs and others, 1982[a], [b]). Two cores were drilled during the 1976-77 austral summer on either side of a prominent $4.4 \mathrm{~m} \mathrm{high}$ brine step (Fig. 3): the 77 High Step and the 77 Low Step cores. During the 1978-79 austral summer, five more 
TABLE II. SAMPLE DEPTHS, MELT-WATER SALINITIES, CHEMICAL CONCENTRATIONS, AND $\mathrm{SO}_{4} / \mathrm{Na}$ RATIOS FOR ALL BRINE-INFILTRATED ICE-CORE SAMPLES FROM THE MCMURDO ICE SHELF, ANTARCTICA

\begin{tabular}{|c|c|c|c|c|c|c|}
\hline Drill core & Sample & $\begin{array}{c}\text { Depth } \\
\text { m }\end{array}$ & $\begin{array}{l}S \\
0 / 00\end{array}$ & $\begin{array}{l}\mathrm{Na} \\
\mathrm{g} / 1\end{array}$ & $\mathrm{SO}_{\mathrm{g} / 1}$ & $\mathrm{SO}_{4} / \mathrm{Na}$ \\
\hline A & $\begin{array}{l}\mathrm{I}-1 \\
\mathrm{I}-2 \\
\mathrm{I}-3 \\
\mathrm{I}-4 \\
\mathrm{I}-5\end{array}$ & $\begin{array}{l}2.60-2.70 \\
3.10-3.20 \\
4.00-4.10 \\
4.70-4.80 \\
8.30-8.40\end{array}$ & $\begin{array}{l}4.2 \\
5.7 \\
3.0 \\
3.3 \\
3.2\end{array}$ & $\begin{array}{l}1.3 \\
1.9 \\
1.1 \\
1.2 \\
1.5\end{array}$ & $\begin{array}{l}0.28 \\
0.43 \\
0.19 \\
0.24 \\
0.24\end{array}$ & $\begin{array}{l}0.22 \\
0.23 \\
0.17 \\
0.20 \\
0.16\end{array}$ \\
\hline B & $\begin{array}{l}4-B \\
4-C \\
4-D \\
4-E \\
4-F \\
4-G \\
4-H \\
4-J \\
4-\mathrm{K} \\
4-\mathrm{L} \\
4-\mathrm{M} \\
4-\mathrm{N} \\
4-\mathrm{O} \\
4-\mathrm{P}\end{array}$ & $\begin{array}{l}8.95-9.05 \\
9.05-9.15 \\
9.15-9.25 \\
9.25-9.35 \\
9.35-9.45 \\
9.45-9.55 \\
9.55-9.65 \\
9.75-9.85 \\
9.85-9.95 \\
9.95-10.05 \\
10.05-10.15 \\
10.15-10.25 \\
10.25-10.35 \\
10.35-10.45\end{array}$ & $\begin{array}{r}6.9 \\
8.2 \\
7.4 \\
7.2 \\
4.9 \\
2.9 \\
3.7 \\
2.2 \\
3.0 \\
3.0 \\
2.5 \\
3.1 \\
3.1 \\
-\end{array}$ & $\begin{array}{l}2.2 \\
2.6 \\
2.4 \\
2.4 \\
1.8 \\
1.2 \\
1.4 \\
1.1 \\
0.95 \\
1.15 \\
1.15 \\
1.1 \\
1.1 \\
1.0\end{array}$ & $\begin{array}{l}0.65 \\
0.73 \\
0.68 \\
0.65 \\
0.40 \\
0.24 \\
0.31 \\
0.23 \\
0.20 \\
0.25 \\
0.26 \\
0.22 \\
0.23 \\
0.21\end{array}$ & $\begin{array}{l}0.29 \\
0.28 \\
0.28 \\
0.27 \\
0.22 \\
0.20 \\
0.22 \\
0.21 \\
0.21 \\
0.22 \\
0.23 \\
0.20 \\
0.21 \\
0.21\end{array}$ \\
\hline $\begin{array}{l}77 \text { High } \\
\text { Step }\end{array}$ & $\begin{array}{c}1-A \\
1-B \\
2 \\
3 \\
4-A \\
4-C \\
5-A \\
5-B \\
5-D\end{array}$ & $\begin{array}{l}17.05-17.25 \\
17.25-17.40 \\
17.54-17.64 \\
17.72-17.92 \\
17.95-18.05 \\
18.15-18.27 \\
18.30-18.40 \\
18.45-18.55 \\
18.70-18.76\end{array}$ & $\begin{array}{l}15.2 \\
13.0 \\
12.2 \\
16.0 \\
14.0 \\
15.5 \\
16.0 \\
12.6 \\
13.0\end{array}$ & $\begin{array}{l}5.0 \\
4.0 \\
3.7 \\
4.4 \\
4.2 \\
5.4 \\
3.9 \\
4.1 \\
3.9\end{array}$ & $\begin{array}{r}3.8 \\
2.2 \\
2.5 \\
2.6 \\
2.1 \\
- \\
2.3 \\
2.5 \\
2.4\end{array}$ & $\begin{array}{l}0.68 \\
0.55 \\
0.65 \\
0.59 \\
0.50 \\
- \\
0.56 \\
0.59 \\
0.62\end{array}$ \\
\hline $\begin{array}{l}77 \text { Low } \\
\text { Step }\end{array}$ & $\begin{array}{l}33-\mathrm{B} \\
33-\mathrm{C} \\
33-\mathrm{D} \\
34-\mathrm{B}\end{array}$ & $\begin{array}{l}22.05-22.15 \\
22.15-22.20 \\
22.20-22.25 \\
22.31-22.41\end{array}$ & $\begin{array}{l}15.0 \\
25.5 \\
30.0 \\
30.0\end{array}$ & $\begin{array}{r}3.5 \\
6.4 \\
8.7 \\
11.0\end{array}$ & $\begin{array}{l}0.32 \\
0.68 \\
0.57 \\
0.60\end{array}$ & $\begin{array}{l}0.091 \\
0.110 \\
0.063 \\
0.055\end{array}$ \\
\hline 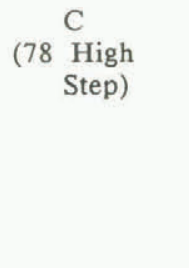 & $\begin{array}{l}C-2 \\
C-3 \\
Z-1 \\
Z-2 \\
Z-3 \\
Z-4 \\
Z-5 \\
Z-7\end{array}$ & $\begin{array}{l}19.55-19.69 \\
19.69-19.95 \\
19.95-20.10 \\
20.10-20.20 \\
20.20-20.30 \\
20.30-20.40 \\
20.40-20.50 \\
20.80-20.95\end{array}$ & $\begin{array}{r}14.0 \\
8.9 \\
13.5 \\
15.3 \\
- \\
10.5 \\
11.0 \\
8.1\end{array}$ & $\begin{array}{l}4.7 \\
3.2 \\
4.7 \\
5.3 \\
3.1 \\
3.8 \\
3.6 \\
3.1\end{array}$ & $\begin{array}{l}1.25 \\
0.95 \\
1.45 \\
2.1 \\
0.95 \\
1.4 \\
1.1 \\
0.75\end{array}$ & $\begin{array}{l}0.27 \\
0.30 \\
0.31 \\
0.40 \\
0.31 \\
0.37 \\
0.31 \\
0.24\end{array}$ \\
\hline $\mathrm{D}$ & $\begin{array}{l}\text { B-1 } \\
\text { B-2 } \\
\text { B-3 } \\
\text { B-4 } \\
\text { B-5 } \\
\text { B-6 } \\
\text { B-7 } \\
\text { B-8 } \\
\text { B-9 } \\
\text { B-T } \\
\text { B-M } \\
\text { B-B }\end{array}$ & $\begin{array}{l}33.70-33.84 \\
33.84-34.00 \\
34.00-34.16 \\
34.16-34.36 \\
34.39-34.54 \\
34.54-34.69 \\
34.69-34.84 \\
34.84-34.99 \\
34.99-35.22 \\
35.22-35.32 \\
35.94-36.04 \\
36.57-36.67\end{array}$ & $\begin{array}{r}0.4 \\
0.4 \\
1.8 \\
4.4 \\
5.3 \\
13.1 \\
14.6 \\
8.1 \\
10.8 \\
13.4 \\
9.5 \\
11.0\end{array}$ & $\begin{array}{l}0.10 \\
0.08 \\
0.45 \\
1.3 \\
1.5 \\
3.5 \\
3.8 \\
2.8 \\
3.6 \\
4.1 \\
2.6 \\
3.2\end{array}$ & $\begin{array}{l}<0.01 \\
0.004 \\
0.014 \\
0.034 \\
0.042 \\
0.100 \\
0.110 \\
0.080 \\
0.090 \\
0.115 \\
0.090 \\
0.085\end{array}$ & $\begin{array}{l}<0.10 \\
0.049 \\
0.031 \\
0.026 \\
0.028 \\
0.029 \\
0.029 \\
0.029 \\
0.025 \\
0.027 \\
0.035 \\
0.028\end{array}$ \\
\hline $\mathrm{E}$ & $\begin{array}{l}\text { A-C } \\
A-D \\
A-E \\
A-F \\
A-G \\
A-I \\
B-A \\
B-B \\
B-C \\
B-D \\
B-E \\
B-F \\
B-G \\
B-H \\
\text { C-A } \\
\text { C-B } \\
\text { C-C } \\
\text { C-E } \\
\text { Free } \\
\text { brine }\end{array}$ & $\begin{array}{c}50.47-50.57 \\
50.57-50.67 \\
50.67-50.77 \\
50.77-50.87 \\
50.87-50.97 \\
51.07-51.17 \\
51.17-51.29 \\
51.29-51.39 \\
51.39-51.50 \\
51.50-51.60 \\
51.60-51.70 \\
51.70-51.81 \\
51.81-51.94 \\
51.94-52.07 \\
52.07-52.16 \\
52.16-52.25 \\
52.25-52.34 \\
52.43-53.52 \\
\text { Bottom of } \\
\text { hole }\end{array}$ & $\begin{array}{r}2.0 \\
1.3 \\
3.0 \\
2.2 \\
1.0 \\
10.1 \\
7.0 \\
9.2 \\
2.7 \\
2.2 \\
15.0 \\
4.1 \\
1.4 \\
9.6 \\
14.6 \\
0.2 \\
2.1 \\
3.2 \\
\approx 200\end{array}$ & $\begin{array}{l}0.60 \\
0.39 \\
0.81 \\
0.67 \\
0.34 \\
3.8 \\
3.2 \\
2.8 \\
0.87 \\
0.57 \\
4.0 \\
1.8 \\
0.32 \\
2.1 \\
5.0 \\
0.10 \\
0.70 \\
0.98 \\
62\end{array}$ & $\begin{array}{l}0.018 \\
0.012 \\
0.026 \\
0.020 \\
0.010 \\
0.120 \\
0.075 \\
0.080 \\
0.026 \\
0.015 \\
0.080 \\
0.036 \\
0.008 \\
0.065 \\
0.130 \\
\approx 0.002 \\
0.020 \\
0.028 \\
\\
2.1\end{array}$ & $\begin{array}{l}0.030 \\
0.031 \\
0.032 \\
0.030 \\
0.029 \\
0.032 \\
0.023 \\
0.029 \\
0.030 \\
0.026 \\
0.020 \\
0.020 \\
0.025 \\
0.031 \\
0.026 \\
0.020 \\
0.029 \\
0.029 \\
0.034\end{array}$ \\
\hline $\begin{array}{l}\text { Copenhagen } \\
\text { Copenhagen }\end{array}$ & $\begin{array}{l}\text { Standard } \\
\text { Standard }\end{array}$ & $\begin{array}{l}\text { eawater, observed } \\
\text { eawater, expected* }\end{array}$ & 34.5 & $\begin{array}{l}10.4 \\
11.0\end{array}$ & $\begin{array}{l}2.76 \\
2.79\end{array}$ & $\begin{array}{l}0.27 \\
0.25\end{array}$ \\
\hline
\end{tabular}

*From Riley and Chester $(1971$, p. 84$)$. 
TABLE III. CONCENTRATIONS OF $\mathbf{K}, \mathrm{Ca}, \mathrm{Mg}$, AND $\mathrm{Cl}$ IN SELECTED BRINE SAMPLES, AND CORRESPONDING IONIC RATIOS

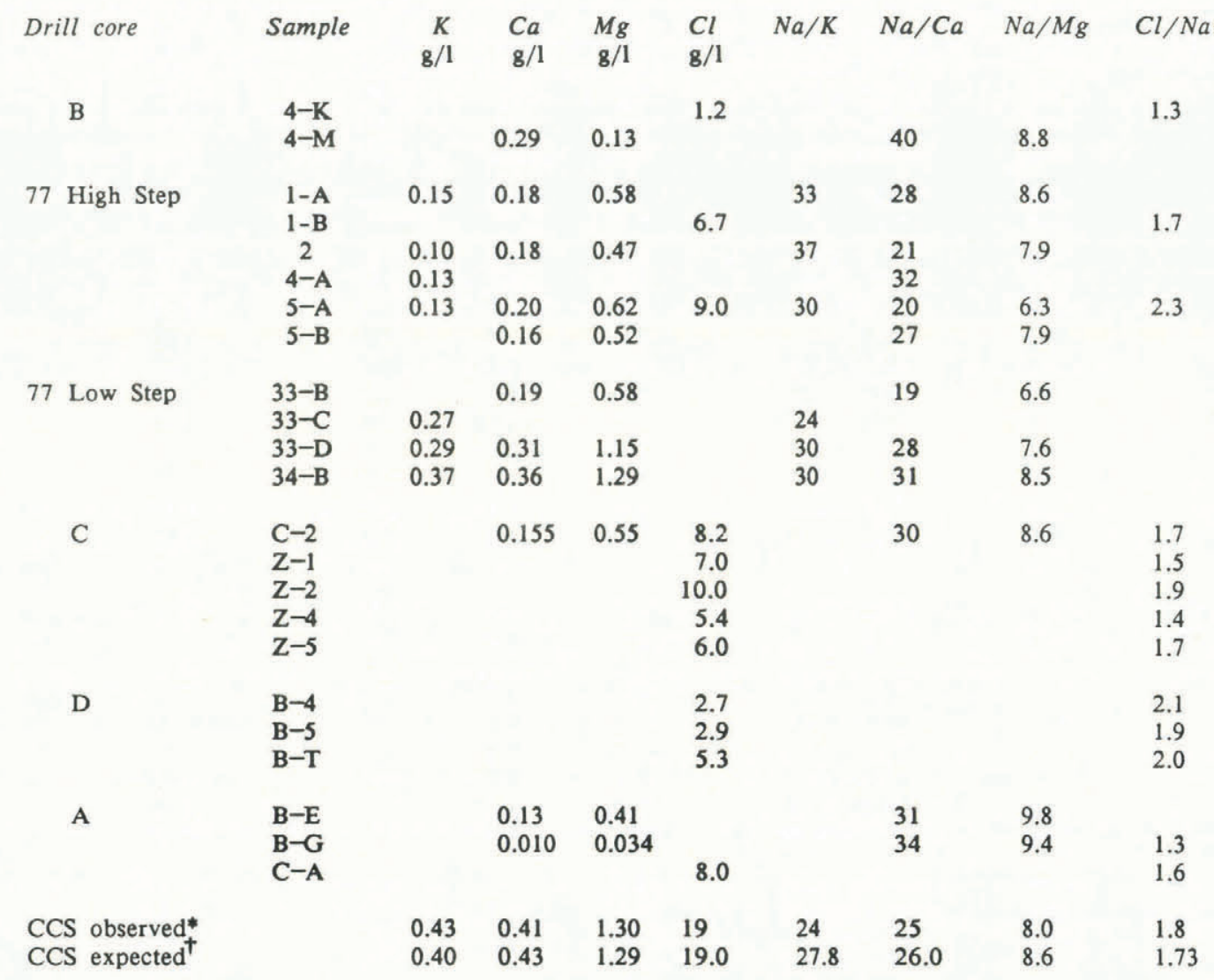

*Copenhagen Standard Seawater.

†From Riley and Chester (1971, p. 84).

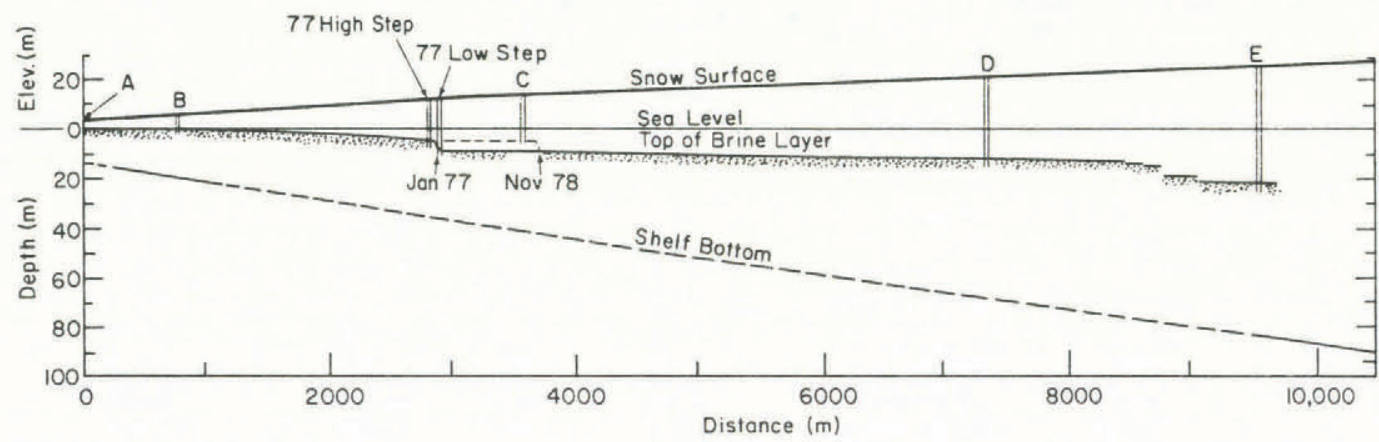

Fig. 2. Cross-section of the McMurdo Ice Shelf showing the top of the brine zone and core-drilling locations. The 10 January 1977 and 24 November 1978 positions of the $4.4 \mathrm{~m}$ brine step and a series of steps near the inland boundary of brine penetration are also shown.

cores were drilled at locations A, B, C, D, and E. Figure 2 is drawn for the brine layer as it existed in January 1977. Observations made during the second field season (November 1978) showed that the brine step had further infiltrated the ice shelf and that it was now located at position $C$, a net inland movement of $700 \mathrm{~m}$ in a little less than 2 years (Kovacs and others, 1982[b]).

\section{Preliminary observations}

This discovery of a migrating brine step determined for the first time the dynamic wave-like nature of brine infiltration in the McMurdo Ice Shelf. According to our perception of events, the 77 High Step core penetrated the leading edge or nose of a brine wave riding on top of an older brine layer from which the 77 Low Step cores were obtained just a few meters beyond the 77 High Step drill core. Preliminary chemical analyses conducted before the brine step was re-surveyed in November 1978 showed that brines from the 77 Low Step core had appreciably lower $\mathrm{SO} / \mathrm{Na}$ ratios than brines from the 77 High Step core. At that time we interpreted this as indicating the presence of two chemically distinct brine layers in the immediate vicinity of the brine step.

Brine chemistry

Tables II and III present the complete data of chemical concentrations and ionic weight ratios for samples from all seven drill holes. It should be noted that sample salinities and elemental concentrations vary because the brine has been diluted with melt water from the firn of the cores. 


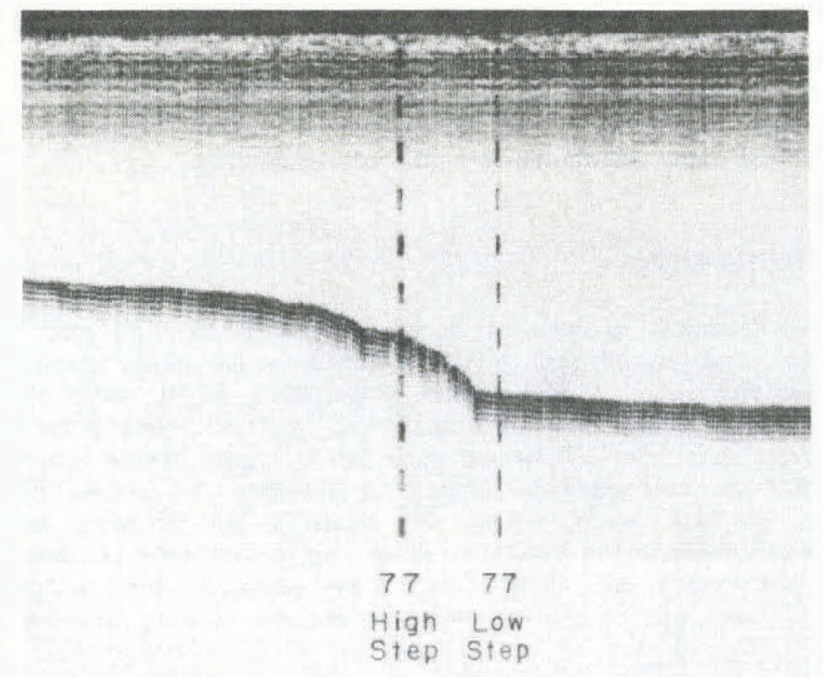

Fig. 3. Graphic record of radio-echo data showing the $4.4 \mathrm{~m}$ high brine step in the McMurdo Ice Shelf as it appeared in January 1977. Locations of the 77 High Step and 77 Low Step drill holes are also indicated. Distance between drill holes is approximately $60 \mathrm{~m}$.

This dilution results in all samples having salinities and concentrations very much less than those of sea-water. The amount of dilution is different for each sample so chemical concentrations or salinities per se cannot be used directly to determine whether any salts are selectively precipitated. However, because the dilution water is known to be derived from firn, which is chemically much purer than sea-water, ratios of elemental concentrations are not affected by dilution and should reveal any chemical fractionation that has occurred. The purity of McMurdo Ice Shelf firn is shown by chemical analysis of four samples from above the brine zone in the 77 High Step core where Na concentrations averaged $4.3 \mathrm{mg} / 1$, which is approximately three orders of magnitude less than $\mathrm{Na}$ concentrations in the brine-soaked firn.

A plot of $\mathrm{Na}$ concentration versus salinity shows a linear relationship with a least-squares slope of $0.299(r=$ 0.972 ). This agrees well with the expected slope of 0.319 for unfractionated sea-water. There is no discernible difference between the $\mathrm{Na}$ /salinity ratio of fractionated and unfractionated core samples. Most of the scatter at the high-salinity end of the curve is caused by samples from the 77 Low Step and 77 High Step cores where, as will be discussed later, chemical fractionation of the brine was actively taking place.

In studies of chemical fractionation of sea-water, $\mathrm{NaCl}$ is generally considered to be chemically conservative, and elemental ratios are usually calculated relative to $\mathrm{Cl}$ or $\mathrm{Na}$ (Duce and others, 1972). We used $\mathrm{Na}$ as the reference element simply because the analytical measurement was less time-consuming than that for $\mathrm{Cl}$.

Sulfate is the primary ion of interest. When sea-water freezes, one of the first major salts to separate is sodium sulfate decahydrate (mirabilite), $\mathrm{Na}_{2} \mathrm{SO}_{4} \cdot 10 \mathrm{H}_{2} \mathrm{O}$, which begins to precipitate at $-8.2^{\circ} \mathrm{C}$ after sufficient water has been removed as ice (Lewis and Thompson, 1950; Nelson and Thompson, 1954). Sodium chloride dihydrate $\left(\mathrm{NaCl} \cdot 2 \mathrm{H}_{2} \mathrm{O}\right.$ ) then follows at $-22.9^{\circ} \mathrm{C}$ (Nelson and Thompson, 1954) but the in-situ McMurdo Ice Shelf temperatures, typically $-12^{\circ}$ to $-16^{\circ} \mathrm{C}$ in the deeper parts of the brine zone (Kovacs and others, 1982[b]), are not low enough to cause its precipitation.

The last column in Table II shows the reduction in $\mathrm{SO}_{4} / \mathrm{Na}$ ratio for the brine from drill cores $\mathrm{D}$ and $\mathrm{E}$; $\mathrm{SO}_{4} / \mathrm{Na}$ ratios in the brine layer of this part of the ice shelf are an order of magnitude lower than the normal seawater $\mathrm{SO}_{4} / \mathrm{Na}$ ratio of 0.25 . This lower ratio could be due either to a depletion of $\mathrm{SO}_{4}$ or to an enrichment of $\mathrm{Na}$ relative to $\mathrm{Cl}$. To distinguish between these two mechanisms, we measured $\mathrm{Cl}$ concentrations in 14 samples of high and low salinities, and from fractionated (low $\mathrm{SO} / \mathrm{Na}$ ratio) brines (see Table III). The average $\mathrm{Cl} / \mathrm{Na}$ ratio of $1.8 \pm 0.3$ is the same as the sea-water $\mathrm{Cl} / \mathrm{Na}$ ratio, indicating that $\mathrm{Na}$ is not enriched. Thus, the low $\mathrm{SO}_{4} / \mathrm{Na}$ ratios observed in the brine from cores $\mathrm{D}$ and $\mathrm{E}$ must be due to depletion of $\mathrm{SO}_{4}$.

The $\mathrm{SO}_{4}$ depletion observed in the brine of drill cores $D$ and $E$ could result from precipitation of any of a number of alkali or alkaline-earth salts of sulfate. The question is, which one? The least soluble of the $\mathrm{SO}_{4}$ salts is CaSO, and Richardson (1976) reported the presence of $\mathrm{CaSO}_{4} \cdot 2 \mathrm{H}_{2} \mathrm{O}$ in sea ice. But the average $\mathrm{Na} / \mathrm{Ca}$ ratio (Table III) of three $\mathrm{SO}_{4}$-depleted brine samples is 26 , which is not appreciably higher than the sea-water $\mathrm{Na} / \mathrm{Ca}$ ratio of 25 . Neither do changes in $\mathrm{Ca}$ concentrations parallel changes in $\mathrm{SO}_{4}$ concentrations. Furthermore, there is not enough $\mathrm{Ca}$ in sea-water to precipitate the amount of $\mathrm{SO}_{4}$ that was removed. If all the $\mathrm{Ca}$ in sea-water, $0.43 \mathrm{~g} \mathrm{Ca} / 1$ (21 meq $\mathrm{Ca} / \mathrm{l})$ is removed as $\mathrm{CaSO}_{4}$, then $1.73 \mathrm{~g} \mathrm{SO}_{4} / 1$ (36 meq SO $\left./ 1\right)$ would remain; the $\mathrm{SO}_{4} / \mathrm{Na}$ ratio would then be 0.16 , which is still six times greater than that observed for the fractionated samples. This means that some other cation is removing $\mathrm{SO}_{4}$.

Even though sea-water contains enough $\mathrm{Mg}$ conceivably to remove all of the $\mathrm{SO}_{4}$, the good agreement between the sea-water $\mathrm{Na} / \mathrm{Mg}$ ratio and that of the samples (Table III) indicates that $\mathbf{M g}$ is not being removed. This is probably because the lowest temperature in the ice shelf $\left(-16^{\circ} \mathrm{C}\right)$ is warmer than the observed temperatures of deposition of $\mathrm{MgCl}_{2} \cdot 8 \mathrm{H}_{2} \mathrm{O}$ from sea-water $\left(-18^{\circ} \mathrm{C}\right)$ (Richardson, 1976). Neither does $\mathbf{K}$ appear to be affected, as shown by the $\mathrm{Na} / \mathrm{K}$ ratios.

It is more likely that $\mathrm{Na}_{3} \mathrm{SO}_{4}$ would precipitate, since it is less soluble than $\mathrm{K}_{2} \mathrm{SO}_{4}$ and since sea-water contains a much higher concentration of $\mathrm{Na}$ than of $\mathrm{K}$. In fact, sea-water contains such a high concentration of $\mathrm{Na}$ that precipitation of all $\mathrm{SO}_{4}$ as $\mathrm{Na}_{2} \mathrm{SO}_{4}$ would change the $\mathrm{Na} / \mathrm{K}$ ratio by only $6 \%$ (from a normal 27.8 to 26.1 ). Thus, the high sea-water concentration of $\mathrm{Na}$ permits the $\mathrm{SO}_{4}$ to be removed as $\mathrm{Na}_{2} \mathrm{SO}_{4}$ without causing an appreciable change in the ratios of $\mathrm{Na} / \mathrm{K}, \mathrm{Na} / \mathrm{Mg}$, or $\mathrm{Na} / \mathrm{Ca}$. Also, because of the small relative change in $\mathrm{Na}$ concentration when $\mathrm{Na}_{2} \mathrm{SO}_{4}$ precipitates, changes in the $\mathrm{SO}_{4} / \mathrm{Na}$ ratio essentially reflect changes in the $\mathrm{SO}_{4}$ concentration.

Sulfate is depleted as much as ten-fold in samples from cores E, D, and 77 Low Step (Table II). Cores E and $D$ are the farthest inland from the ice front and correspond to the deepest and oldest brine layers (Fig. 2). Samples from the 77 Low Step cores are also from an older brine zone currently being over-ridden by a new wave of brine that was sampled first at 77 High Step and then approximately 22 months later at location C (see Fig. 2). Samples from these latter two cores together with brine samples from cores $\mathrm{A}$ and $\mathrm{B}$ show no significant $\mathrm{SO}_{4}$ depletion and have $\mathrm{SO}_{4} / \mathrm{Na}$ ratios that are normal or greater than sea-water; this is reasonable because cores $\mathbf{A}$ and $\mathbf{B}$ are located closest to the ice front and contain brine from the most recent intrusion of sea-water.

\section{Brine-wave dynamics}

The brine step at location C, as of 28 November 1978, represents the leading edge of a brine wave migrating through the ice shelf in a direction opposite to the movement of the ice shelf itself. Because of glacial flow, the McMurdo Ice Shelf is moving toward McMurdo Sound at rates of $47-118 \mathrm{~m} /$ year (Heine, 1968), depending upon location. At Heine's station 307, located very close to drill site $\mathrm{E}$, the ice shelf is moving at a measured velocity of $84 \mathrm{~m} /$ year. Drill site $\mathrm{E}$ is very close to the inland boundary of brine infiltration where the rate of migration of the deepest brine layer is only about $12 \mathrm{~m} /$ year (Kovacs and others, 1982[b]). This means that, in terms of its geographical location, the brine terminus is currently moving seaward with the ice shelf at a velocity of about $72 \mathrm{~m} /$ year.

Brine migration within the ice shelf is controlled by the permeability and temperature of the firn and ice, and is maintained or renewed by sea-water entering at the ice front. As demonstrated by Kovacs and others (1982[b]], the overall process of infiltration is dominated by wave-like 

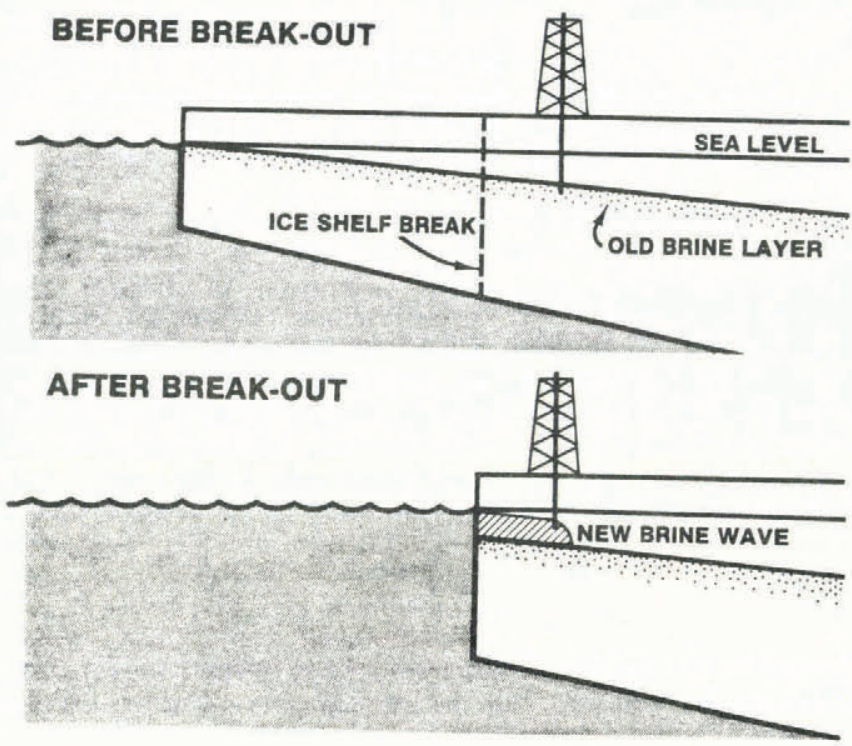

Fig. 4. Schematic of the ice-shelf break-out process showing a new brine wave migrating inland over the old brine layer.

intrusions of sea-water triggered by periodic break-out of the ice front in McMurdo Sound. (See Figure 4 for a schematic of break-out.) The $4.4 \mathrm{~m}$ brine step, originally detected at the 77 High Step and 77 Low Step drill sites and which subsequently migrated to location $C$, represents the most recent example of a wave generated by a major break-out of the McMurdo Ice Shelf. This break-out is postulated to have taken place about 1970. Several other steps (waves) have been identified in radio-echo profiling records by Kovacs and others (1982[b]), including several very prominent steps near the terminal boundary of brine migration.

Infiltration of sea-water into the McMurdo Ice Shelf is accompanied by freeze-concentration of the brine and freeze-fractionation of component salts, particularly mirabilite. The younger brine waves penetrate the ice shelf by simple permeation through porous firn. On 10 January 1977 the leading edge of the $4.4 \mathrm{~m}$ brine wave was located $2.85 \mathrm{~km}$ from the ice-shelf edge and by 24 November 1978 it had migrated to a position $3.55 \mathrm{~km}$ from the ice-shelf edge, an average rate of migration of $1.04 \mathrm{~m} / \mathrm{d}$.

When sufficient water (approximately $80 \%$ ) is removed by freezing and the brine temperature reaches $-8.2^{\circ} \mathrm{C}$, mirabilite begins to precipitate. Precipitation occurs at the leading edge of the brine wave where the salt concentration is the highest and the temperature is lowest. The chemical fractionation is clearly demonstrated in samples from the 77 High Step and 77 Low Step cores. In samples from the 77 High Step core, $\mathrm{SO}_{4} / \mathrm{Na}$ ratios lie between 0.5 and 0.68 (Table II), which is about twice the normal sea-water ratio of 0.25 . This excess $\mathrm{SO}_{4}$ in the 77 High Step samples can be attributed to inclusion of freshly precipitated mirabilite at the forward edge or nose of the brine wave. By contrast, $\mathrm{SO}_{4} / \mathrm{Na}$ ratios in samples from the 77 Low Step core located directly inland of the brine wave are much lower (2.3-4.5 times less) than that of normal sea-water. The 77 Low Step cores are depleted in $\mathrm{SO}_{4}$ because they were obtained from an older fractionated brine layer over which the new brine wave is migrating. The 77 High Step and 77 Low Step cores were taken within $60 \mathrm{~m}$ of each other, so that the dramatic ten-fold change in $\mathrm{SO}_{4} / \mathrm{Na}$ ratios occurs over a very short horizontal distance.

The deepest and oldest brine layer, sampled at drill site E near the inland boundary of brine penetration, contains highly concentrated brine in which the $\mathrm{SO}_{4} / \mathrm{Na}$ ratio is an order of magnitude less than that of normal sea-water (Table II). Despite the fact that this brine is now enclosed within impermeable ice (Kovacs and others, 1982[a]), migration of the brine has not ceased. Movement on the order of $0.04 \mathrm{~m} / \mathrm{d}$ has been measured (Kovacs and others, 1982[b]) and one possible explanation of this continued migration of brine is in the eutectic dissolution of ice by the concentrated brine as it is transported into deeper and warmer parts of the ice shelf by the combined process of surface snow accumulation and bottom melting.

\section{CONCLUSIONS}

Chemical analyses of cores from a $4.4 \mathrm{~m}$ high step in the brine-soaked firn of the McMurdo Ice Shelf confirm that this step is the leading edge of a brine wave that originated from sea-water entering the ice front after a major break-out of the ice shelf in McMurdo Sound around 1970. As the sea-water begins to permeate the porous firn in the ice shelf, water is removed by freezing and concentrated brine begins to form. When the brine reaches a concentration of about five times that of the original sea-water and a eutectic temperature of $-8.2^{\circ} \mathrm{C}$, mirabilite $\left(\mathrm{Na}_{2} \mathrm{SO}_{4} \cdot 10 \mathrm{H}_{2} \mathrm{O}\right)$ begins precipitating at the wave front. As the brine wave advances further inland, mirabilite continues to separate until the residual brine contains less than $10 \%$ of the original sea-water $\mathrm{SO}_{4}$. Once the brine has traveled far enough into the ice shelf to reach the firn-ice transition, further movement of the brine is slowed dramatically by impermeable ice.

Thus, the overall brine zone consists of superimposed waves that originate at the ice-shelf front during ice breakouts and migrate laterally at different velocities, depending on their position within the ice shelf. This wave-like migration through firn, in which brines become increasingly concentrated and dramatically depleted in sulfate, represents the principal mechanism by which sea-water infiltrates the McMurdo Ice Shelf.

\section{ACKNOWLEDGEMENTS}

Field work was supported by a grant from the Division of Polar Programs of the National Science Foundation, grant NSF-DPP 77-19565. Laboratory studies were funded under DA Project 4A161102AT24, Cold Regions Surface Boundary Layer Physics and Chemistry. The authors thank Dr S. Colbeck and D. Leggett, both of CRREL, for reviewing this report and the Polar Ice Coring Office (PICO) of the University of Nebraska for its assistance with core drilling during November 1978.

\section{REFERENCES}

Bertolacini, R.J., and Barney, J.E., II. 1958. Ultraviolet spectrophotometric determination of sulfate, chloride and fluoride with chloranilic acid. Analytical Chemistry, Vol. 30, No. 2, p. 202-05.

Clough, J.W. 1973. Radio echo sounding: brine percolation layer. Journal of Glaciology, Vol. 12, No. 64, p. 141-43.

Cragin, J.H., and others. 1975. The chemistry of 700 years of precipitation at DYE-3, Greenland, by J.H. Cragin, M.M. Herron, and C.C. Langway, jr. U.S. Cold Regions Research and Engineering Laboratory. Research Report 341.

Dubrovin, L.I. 1962. O rassolakh v shel'fovykh lednikakh. [Brine in ice shelves]. Informatsionnyy Byulleten' Sovetskoy Antarkticheskoy Ekspeditsii, No. 35, p. 35-38.

Duce, R.A., and others. 1972. Working symposium on sea-air chemistry: summary and recommendations, by R.A. Duce, W. Stumm, and J.M. Prospero. Journal of Geophysical Research, Vol. 77, No. 27, p. 5059-61.

Heine, A.J. 1968. Brine in the McMurdo Ice Shelf, Antarctica. New Zealand Journal of Geology and Geophysics, Vol. 11, No. 4, p. 829-39.

Kovacs, A., and Gow, A.J. 1975. Brine infiltration in the McMurdo Ice Shelf, McMurdo Sound, Antarctica. Journal of Geophysical Research, Vol. 80, No. 15, p. 1957-61.

Kovacs, A., and Gow, A.J. 1977. Subsurface measurements of the Ross Ice Shelf, McMurdo Sound, Antarctica. Antarctic Journal of the United States, Vol. 12, No. 4, p. 146-48. 
Kovacs, A., and others. 1982[a]. The brine zone in the McMurdo Ice Shelf, Antarctica, by A. Kovacs, A.J. Gow, and J. Cragin. Annals of Glaciology, Vol. 3, p. 166-71

Kovacs, A., and others. 1982[b]. The brine zone in the McMurdo Ice Shelf, Antarctica, by A. Kovacs, A.J. Gow, J.H. Cragin, and R.M. Morey. CRREL Report 82-39.

Lewis, G.J., jr, and Thompson, T.G. 1950. The effect of freezing on the sulfate/chlorinity ratio of sea water. Journal of Marine Research, Vol. 9, No. 3, p. 211-17.

Nelson, K.H., and Thompson, T.G. 1954. Deposition of salts from sea water by frigid concentration. Journal of Marine Research, Vol. 13, No. 2, p. 166-82.

Rand, J.H. 1976. The USA/CRREL shallow drill. (In Splettstoesser, J.F., ed. Ice-core drilling. Lincoln and London, University of Nebraska Press, p. 133-37.)

Richardson, C. 1976. Phase relationships in sea ice as a function of temperature. Journal of Glaciology, Vol. 17, No. 77 , p. 507-19.

Riley, J.P., and Chester, R. 1971. Introduction to marine chemistry. New York, Academic Press.
Risk, G.F., and Hochstein, M.P. 1967. Subsurface measurements on the McMurdo Ice Shelf, Antarctica. New Zealand Journal of Geology and Geophysics, Vol. 10, No. 2, p. 484-97.

Shafer, H.N.S. 1967. The improved spectrophotometric method for the determination of sulfate with barium chloranilate as applied to coal ash and related materials. Analytical Chemistry, Vol. 39, p. 1719-26.

Stuart, A.W., and Bull, C. 1963. Glaciological observations on the Ross Ice Shelf near Scott Base, Antarctica. Journal of Glaciology, Vol. 4, No. 34, p. 399-414.

Thomas, R.H. 1975. Liquid brine in ice shelves. Journal of Glaciology, Vol. 14, No. 70, p. 125-36.

Wilson, A.T., and Heine, A.J. 1964. The chemistry of ice-shelf brines. Journal of Glaciology, Vol. 5, No. 38, p. 265-67.

Yevteyev, S. 1962. Firn s morskoy vodoy, obnaruzhennyy y shel'fovom lednike Mak-Merdo. [Firn with sea-water in the McMurdo Ice Shelf]. Informatsionnyy Byulleten' Sovetskoy Antarkticheskoy Expeditsii, No. 37, p. 50. 